\title{
Antibiotic resistance and virulence factors among Escherichia coli isolates from avian organic fertilizer
}

\author{
Juliana Maria Avanci Agostinho ${ }^{*}$ (D) Marita Vedovelli Cardozo ${ }^{2}$ (iD \\ Mariana Monezi Borzi (D) José Moacir Marin ${ }^{3}$ (D)
}

${ }^{1}$ Programa de Microbiologia Agropecuária, Universidade Estadual Paulista "Julio de Mesquita Filho" (UNESP), 14884-900, Jaboticabal, SP, Brasil. E-mail: ju avanci@yahoo.com.br. .Correponding author.

${ }^{2}$ Departamento de Patologia Veterinária, Universidade Estadual Paulista “Julio de Mesquita Filho" (UNESP), Jaboticabal, SP, Brasil. ${ }^{3}$ Departamento de Biologia Básica e Oral, Universidade de São Paulo (USP), Ribeirão Preto, SP, Brasil.

\begin{abstract}
Brazilian poultry industry generates large amounts of organic waste, such as chicken litter, which is often used in agriculture. Among the bacteria present in organic fertilizer are members of the Enterobacteriaceae family, such as Escherichia coli. The aim of this study was to analyze the profile of virulence factors and antimicrobial resistance of E. coli isolates from avian organic fertilizer. A total of 47 E. coli strains were tested through Polymerase chain reaction to detect virulence genes (hlyF, iss, ompT, iutA and iroN). Fourteen antimicrobials were used to test antimicrobial susceptibility in the strains. Genes characteristic of Avian Pathogenic E. coli (APEC) were reported among the strains, with the hlyF, iss and ompT genes being the most prevalent. The isolates showed high resistance (>50\%) to tetracycline, gentamicin, cefotaxime, nitrofurantoin, trimethoprim-sulfamethoxazole and ampicillin. Multidrug resistance was reported in a great number of strains $(>70 \%)$. The results showed the presence of APEC cells with virulence genes and antimicrobial resistance after 15 days of the windrowing process in poultry houses, it means this process should be improved to eliminate these cells.
\end{abstract}

Key words: poultry production, Enterobacteriacea, zoonotic risk, virulence factors.

Resistência a antibióticos e fatores de virulência entre isolados de Escherichia coli provenientes de fertilizante orgânico aviário

RESUMO: A indústria avícola brasileira gera grandes quantidades de resíduos orgânicos, como a cama de frango, utilizada frequentemente na agricultura. Entre as bactérias presentes neste fertilizante orgânico estão os membros da família Enterobacteriaceae, entre eles a Escherichia coli. O objetivo deste estudo foi analisar o perfil de fatores de virulência e resistência antimicrobiana de isolados de E. coli provenientes do fertilizante orgânico aviário. Um total de 47 cepas de E. coli foram testadas por meio da reação em cadeia da polimerase para detectar genes de virulência (hlyF, iss, ompT, iutA e iroN). Quatorze antimicrobianos foram utilizados para testar a susceptibilidade antimicrobiana nos isolados. Genes característicos de E. coli Patogênica Aviária (APEC) foram encontrados entre os isolados, sendo os genes hlyF, iss e ompT os mais prevalentes. Os isolados apresentaram alta resistência (>50\%) à tetraciclina, gentamicina, cefotaxima, nitrofurantoina, trimetoprimasulfametoxazole e ampicilina. Múltipla resistência a drogas antimicrobianas foi encontrada em grande número de isolados (>70\%). Os resultados obtidos mostraram a presença de células APEC portando genes de virulência e resistência a antimicrobianos após 15 dias de processo de empilhamento nas granjas, indicando que o processo necessita de um aperfeiçoamento para eliminar estas células.

Palavras-chave: produção avícola, Enterobacteriaceae, risco zoonótico, fatores de virul

\section{INTRODUCTION}

The poultry industry is an important part of the economy in Brazil which is one of the world's most important producers and the leading exporter of chicken meat (ABPA, 2018). Each year, billions of kilograms of poultry litter are produced in Brazil, so as a waste-saving measure, farms are encouraged to reuse poultry manure as fertilizer. Poultry litter is primarily composted for use in crops production.
The use of improperly composted or non-composted manure as organic fertilizer spread directly onto soil can cause microbiological foodborne illnesses associated with the consumption of fresh fruits or vegetables (OLAIMAT \& HOLLEY, 2012).

In Brazil a normative instruction from government (BRASIL, 1999) indicated the necessity of a decomposition process of the poultry litter without a fixation of time for the process, before the application of this material to soil. SILVA et al., 
(2007) recommended at least 12 days of fermentative process for the poultry litter arranged in piles covered with polyethylene cover in the chicken houses. Due to economic reasons litter is often reutilized for several flocks, sometimes for 6 consecutives flocks (SONODA et al., 2012). During downtime between flocks the poultry litter is subjected to an in-house treatment aiming to reduce or inactivating residual microorganisms (VAZ et al., 2017). Studies have been indicated that manure-borne pathogens can survive in secondary habitats (i.e., manures, soils, and water) for weeks or even months, with their survival depending on the organism and soil biological, chemical, and physical conditions (ISHII et al., 2010).

E. coli is a normal inhabitant of the gastrointestinal tracts of humans and animals ;however, some strains are known to be pathogenic. $E$. coli strains that cause disease outside the intestine are known as extraintestinal pathogenic E. coli (ExPEC) and include human uropathogenic E. coli (UPEC) and avian pathogenic E. coli (APEC) that is a large infectious agent present in chickens which causes economic losses to the poultry industry worldwide (KOGA et al., 2015). Regarding of host of origin ExPEC strains share many traits (JOHNSON et al., 2012. Some studies have indicated a overlapping of the characteristics between APEC and human ExPEC, leading to the hypothesis of a zoonotic potential of poultry strains (CUNHA et al., 2017). The avian intestines have been considered as a reservoir of potential $E$. coli with zoonotic potential that could be transferred directly from birds to humans. (EWERS et al., 2009).

There is not a consensus on how to define the APEC pathotype regarding its virulence traits. However, most of the authors accepted that the presence of these five genes act as minimal predictors (hly $\mathrm{F}$, iss, iro $\mathrm{N}, \operatorname{omp} \mathrm{T}$ and iut $\mathrm{A}$ ), all of them are encoding plasmid-associated virulence factors and can indicate if an $E$. coli strain has a potential to cause extra-intestinal diseases in birds (JOHNSON et al., 2008, STELLA et al., 2016). According JOHNSON et al., (2007) in APEC strains the virulence and antibiotic resistance genes are often carried on the same genetic elements, plasmids like the Col V.

Antimicrobial agents have been used in food-producing animals for a long time. However, increases in antimicrobial-resistant bacteria, both in humans and animals, have generated significant concern regarding food safety (ASAI et al., 2014). Currently chicken products are suspected to be sources of foodborne pathogens and/or antimicrobialresistant bacteria for humans (MARSHALL \& LEVY, 2011). Multidrug-resistant bacteria are frequently reported in poultry (JOHNSON et al., 2012). It is supposed that their presence was an answer to the selective pressure due to the indiscriminate use of antimicrobials in aviculture as feed additives or as therapy (MARSHALL \& LEVY, 2011).

There are gaps in the knowledge about the survival of $E$. coli in avian organic fertilizer, such as the environmental risk for human heath for the use of improperly composted poultry litter, so the aim of this study was to analyze the profile of virulence factors and antimicrobial resistance of $E$. coli isolates from avian organic fertilizer.

\section{MATERIALS AND METHODS}

\section{Reutilization of poultry litter (windrowing)}

According to VAZ et al., (2017) after the removal of the poultry floc, the caked portions of the bedding material are eliminated and the remaining litter was windrowed at the center of the poultry house, forming a single pile, which was covered with a $200 \mu \mathrm{m}$ non-breathable black tarpaulin for 10 days. Then the tarpaulin was removed, and the litter was redistributed throughout the poultry house for a new poultry flock housing. After each grow out the litter was windrowed and after that the material was ready for land apply.

\section{Bacterial isolates}

Poultry litter were obtained from two different farms located in Ituverava, SP, Brazil. The poultry litters came from the same grow out cycle (three) in both farms, and the bedding material used was peanut hulls. The litters were mixed and arranged in two $1,2 \mathrm{~m}^{3}$ piles to deep stacking. Samples were gathered at 5, 10, 15, 30 and 60 days after the beginning of fermentative process (windrowing). In brief, $2 \mathrm{~g}$ of litter sample was inoculated in BHI broth (Brain Heart Infusion) and incubated for 24 hours at $37{ }^{\circ} \mathrm{C}$. After incubation, the content was streaked out on MacConkey agar and incubated for 24 hours at $37^{\circ} \mathrm{C}$. The colonies (five per plate) with typical E. coli characteristics were biochemically identified through the indole production, methyl red and VogesProskauer reactions, citrate utilization, production of urease and hydrogen sulfide (H2S) after incubation for 24 and 72 hours at $37^{\circ} \mathrm{C}$ (KONEMAN et al., 2001).

Poultry litter temperature and $\mathrm{pH}$ were measured every day for 8 days, and afterward, these parameters were checked with a lag 4 days.

\section{Virulence factor genes}

Five genes encoding virulence factors were investigated. The selected genes were $h l y \mathrm{~F}$ 
(putative avian hemolysin), iss (episomal increased serum survival gene), iroN (salmochelin siderophore receptor gene), omp T (episomal outer membrane protease gene) and iucA (aerobactin siderophore receptor gene). The microbial DNA template was obtained based on a thermal lysis technique (KESKIMAKI et al., 2001). Isolates identified as $E$. coli were subjected to polymerase chain reaction (PCR). The PCR reaction was done as described by JOHNSON et al., (2008). PCR amplicons were visualized on $2.0 \%$ agarose gel stained with ethidium bromide. After gel electrophoresis the images were captured using an Image Capture system.

\section{Antimicrobial susceptibility testing}

Antimicrobial susceptibility testing of $E$. coli isolates was performed using the standard diskdiffusion method recommended by the Clinical and Laboratory Standards Institute (CLSI 2008, 2013). Isolates showing intermediate or full resistance were classified as resistant in this study because these drugs would no longer be useful in treating a human infection once the bacteria has intermediate resistance. Antimicrobials used included the following: nalidixic acid (NAL, $30 \mu \mathrm{g}$ ); ampicillin (AMP, $10 \mu \mathrm{g}$ ); amoxicillin-clavulanic acid (AMC, 20/10 $\mu \mathrm{g}$ ); cefoxitin (CFO, $30 \mu \mathrm{g}$ ); cefazolin (CTZ, $30 \mu \mathrm{g})$; cefotaxime (CTX, $30 \mu \mathrm{g})$; ceftazidime (CEF, $30 \mu \mathrm{g}$ ); ciprofloxacin (CIP, $10 \mu \mathrm{g}$ ); chloramphenicol (CLO, $300 \mu \mathrm{g})$; gentamicin (GEN,10 $\mu \mathrm{g}$ ); nitrofurantoin (NIT, $300 \mu \mathrm{g}$ ); norfloxacin (NOR, $10 \mu \mathrm{g}$ ); trimethoprim-sulfamethoxazole (SUT, $1.25 / 23.75 \mu \mathrm{g}$ ); tetracycline (TET, $30 \mu \mathrm{g}$ ). All the antimicrobial drugs tested were usually used in veterinary applications. The E. coli isolate ATCC 25922 was used as a quality control to antimicrobial susceptibility testing, and the results were interpreted as per CLSI criteria. Isolates were classified as multidrug resistance (MDR) according to previously described criteria (MAGIORAKOS et al., 2012).

\section{Statistical analysis}

Frequencies were compared among different groups by using the Fisher exact test and the chi-square test. Findings were considered significant for $p \leq 0.05$. The tests were performed with the statistical program R version 3.1.0 (R Foundation for Statistical Computing, Vienna Austria).

\section{RESULTS}

The temperature and the $\mathrm{pH}$ were monitored in the composting system at both heaps since the first day until the sixty day at two depth 30 and 60 centimeters. According figure 1 the temperature ranges from $38^{\circ} \mathrm{C}$ to $26^{\circ} \mathrm{C}$ in both heap and also the $\mathrm{pH}$ range from 9.3 to 8.2 with the most alkaline $\mathrm{pH}$ around the $18^{\text {th }}$ day.

A total of 50 poultry litter samples were collected in the $5^{\text {th }}, 10^{\text {th }}, 15^{\text {th }}, 30$ and 60 days, ;however only in the $5^{\text {th }}$ day and the $15^{\text {th }}$ day E. coli strains were isolated from the litter. In both the first and the second positive collection, the hly gene was the most prevalent and was present in $80.0 \%$ and $94.0 \%$ of isolates respectively, we alsoreported significant difference for most of the genes studied between strains from the first and second positive collection with the exception of iut gene ( $\mathrm{p}>0.05)$ (Table 1). Few strains from the both collections were negative for virulence genes, with 5 strains in the first collection and only one strain from the second collection without any virulence genes present. Table 2 presents, that most of the strains harbored at least two of the targeted genes in both collections' positive days. The most frequent profile found in the first collection was $h l y \mathrm{~F}$, iss, omp $\mathrm{T}$, iut $\mathrm{A}$ while in the second collection was the hly $\mathrm{F}$, iss, omp $\mathrm{T}$.

According to the antimicrobial susceptibility test, strains from the second positive collection showed a higher frequency of antimicrobial resistance than strains from the first collection for most of the antimicrobial tested (Figure 2). Regarding multidrug resistance only two isolates in the first positive collection were sensitive to all the antimicrobial drugs tested while only two isolates in the second collection were resistant to eleven of the antimicrobial drugs tested (Table 3). Most of the isolates in both collections, $1^{\mathrm{a}}(70.0 \%)$ and $2^{\mathrm{a}}$ $(94.0 \%)$ harbored resistance to three or more of the antimicrobial drugs.

\section{DISCUSSION}

The feasibility of chicken production depends on the economic and environmental sustainability of the management system of the poultry litter discard. In Brazil, reuse of poultry litter is considered when the previous flocks did not present clinical or subclinical infection during housing (VAZ et al., 2017) and the litter can be reused for six cycles of chicken growing (VAZ et al., 2017).

Composting is one of the most suitable technologies for disposing livestock manures. A correct process depends on temperature and $\mathrm{pH}$ for a sanitation effect, and both depending of a correct balance between the carbon and nitrogen $(\mathrm{C} / \mathrm{N})$ 


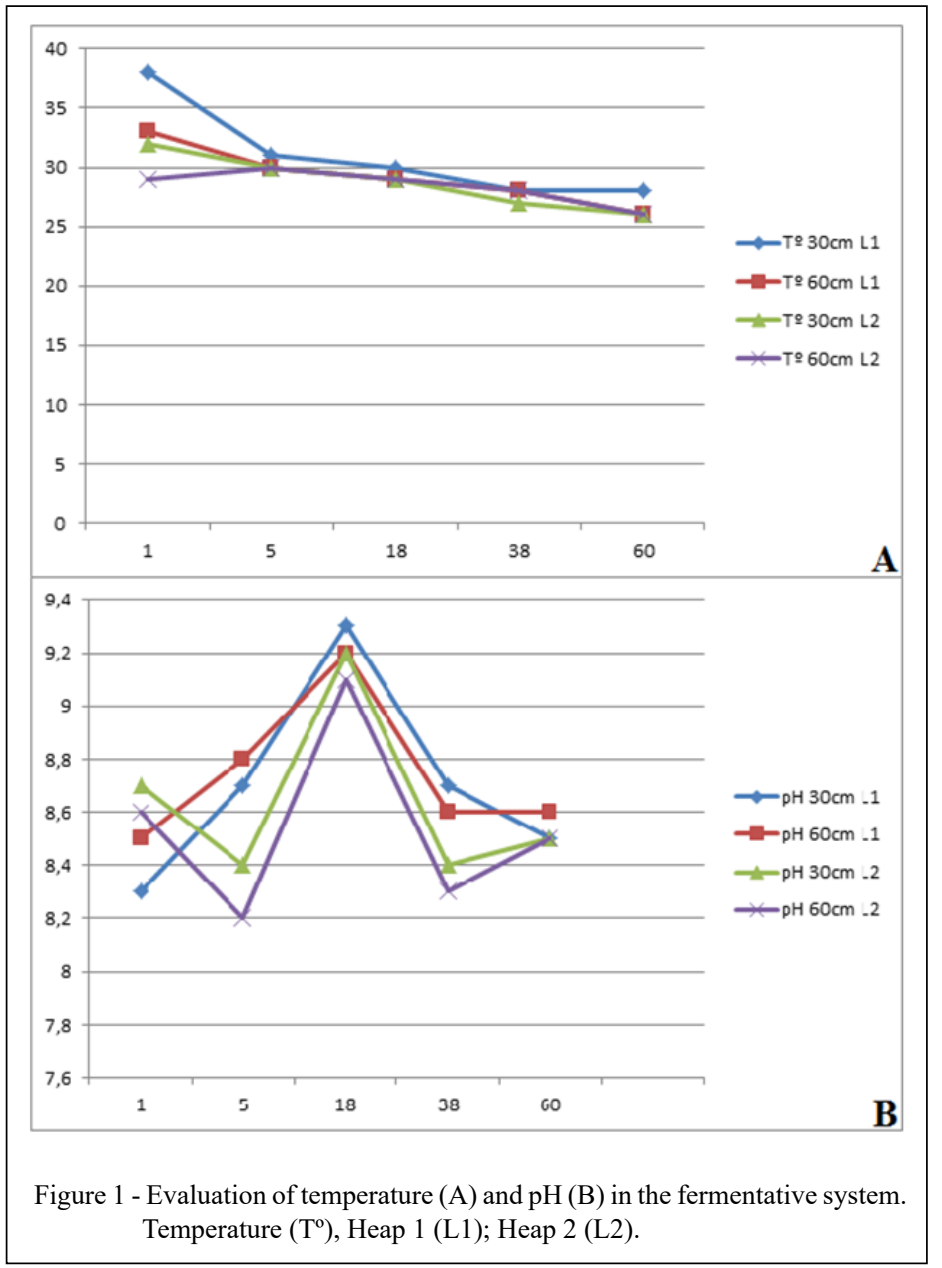

1 to permit a thermophilic phase with temperatures 2 above $55-60{ }^{\circ} \mathrm{C}$ for at least 3 days (ISHII et al., 3 2010). However, the organic waste may not always 4 be suitable for a correct composting, it means that sometimes it is necessary to increase the carbon disposable by adding an additional biodegradable organic matter and active biomass to the occurrence of the thermophilic phase (SONG et al., 2014).

Table 1 - Prevalence of virulence genes among strains of Escherichia coli isolated from poultry litter in Ituverava, SP, Brazil, 2018.

\begin{tabular}{lcc}
\hline & $\begin{array}{c}\text { First positive collection }(\mathrm{n}=30) \\
\mathrm{N}^{\mathrm{o}} \text { of isolates }(\%)\end{array}$ & $\begin{array}{c}\text { Second positive collection }(\mathrm{n}=17) \\
\mathrm{N}^{\mathrm{o}} \text { of isolates }(\%)\end{array}$ \\
\hline Virulence genes & $24(80.0)$ & $16(94.0)$ \\
$h l y \mathrm{~F}^{*}$ & $18(54.0)$ & $15(88.2)$ \\
$i s s^{*}$ & $18(54.0)$ & $15(88.2)$ \\
omp $\mathrm{T}^{*}$ & $0(0)$ & $1(5.8)$ \\
iro $\mathrm{N}^{*}$ & $19(63.3)$ & $7(41.0)$ \\
iut $\mathrm{A}^{* *}$ & & \\
\hline
\end{tabular}

${ }^{*} P \leq 0.05 ;{ }^{* *} p>0.05$.

Ciência Rural, v.50, n.2, 2020. 
Table 2 - Genetic profiles of Escherichia coli strains isolated from poultry litter in Ituverava, SP, Brazil, 2018.

\begin{tabular}{|c|c|c|}
\hline \multirow{2}{*}{ Pathotype genes } & First positive collection & Second positive collection \\
\hline & Number of isolates $(\%)$ & Number of isolates (\%) \\
\hline hly $\mathrm{F}$, iss, omp $\mathrm{T}$ & $2(6.6)$ & $7(41.1)$ \\
\hline$h l y \mathrm{~F}$, iss, omp $\mathrm{T}$, iut $\mathrm{A}$ & $10(33.3)$ & $6(35.2)$ \\
\hline hlyF, iss, iut $\mathrm{A}$ & $6(20.0)$ & $1(5.8)$ \\
\hline hly $\mathrm{F}$, omp $\mathrm{T}$ & $5(16.6)$ & $1(5.8)$ \\
\hline$h l y \mathrm{~F}$, omp $\mathrm{T}$, iut $\mathrm{A}$ & $1(3.3)$ & ------ \\
\hline hly $\mathrm{F}$, iss, omp $\mathrm{T}$, iro $\mathrm{N}$ & ------ & $1(5.8)$ \\
\hline$i u t \mathrm{~A}$ & $2(6.6)$ & ------- \\
\hline None & $4(16.6)$ & $1(5.8)$ \\
\hline
\end{tabular}

In the windrowing technique only the poultry litter was piled and covered with a black tarpaulin promoting an incomplete composting process, actually a fermentative process with low temperatures $\left(<50 \quad{ }^{\circ} \mathrm{C}\right)$ depending on the bedding material used in the poultry houses (VAZ et al., 2017). In the present research the temperature reaches a maximum of $38{ }^{\circ} \mathrm{C}$ what was not enough for a good thermophilic phase. Almost the same temperature 35 to $40{ }^{\circ} \mathrm{C}$ range was reported by WILKINSON et al., (2011) in the static windrow during the period of 21 to 63 day in a trial with poultry litter. Also, SONG et al., (2014) described a composting of chicken manure in which the temperature was 38 to $40{ }^{\circ} \mathrm{C}$ until the fourteen day of the trial. The low temperature in all the trials can be explained for the bad proportion of $\mathrm{C} / \mathrm{N}$ in the bedding material used in the chicken house. To reach the correct temperature of composting should be necessary to increase the green material in the litter maybe adding to the peanut hulls some elephant grass also used in chicken litters to improve the $\mathrm{C} / \mathrm{N}$ balance.

In this study the $\mathrm{pH}$ of the poultry litter rang for 8.2 to 9.3 during the trial. SONG et al., (2014) reported a $\mathrm{pH}$ of 8.7 in the fourteen day of trial, SONODA et al., (2012) reported a $\mathrm{pH}$ of 8.8 and VAZ et al., (2017) reported a mean value of $\mathrm{pH}$ around 9.0 , all of them agreeing with the present study and using the same windrowing method. The increased $\mathrm{pH}$ was most likely the result of ammonia releases due to ammonification (BUSTAMANTE et al., 2008).

SILVA et al., (2007) reported that the number of $E$. coli isolates recovered from poultry litter after 3 flocks grow out decreased for $1 / 3$ of the $E$. coli number recovered in the first flock grow out, this effect is kept in the $4^{\text {th }}$ and $5^{\text {th }}$ flocks grow out. They also reported a re-growing of the $E$. coli cells in poultry litter during the $6^{\text {th }}$ flock grow out. Based on this report we decided to use poultry litter from the $3^{\text {th }}$ flock grow out in this trial, it means the trial begin with the smallest number of $E$. coli cells present in the poultry litter. In the present study E. coli cells were isolated only in two sampling days the $5^{\text {th }}$ and the $15^{\text {th }}$. MARTIN et al., (1998) described that total coliforms were not detected in $94 \%$ of the Georgia poultry litter samples they tested. Likewise, BROOKS et al., (2015) demonstrated an inability to detect common bacterial pathogens in the litter, in the same line WINKLER et al., (2017) described that E. coli levels in poultry litter were often below the limit of detection (10 CFU $\mathrm{g}^{-1}$ ) in samples collected at farms in Texas. In Brazil, GAZAL et al., (2015) reported an isolation of E. coli from $40 \%$ of the samples of avian organic fertilizer. So, it is not uncommon a low frequency of isolation of $E$. coli from avian organic fertilizer. However, we did not have an explication for the absence of $E$. coli isolates from the 10th day, it should be better investigated in other trial.

Earlier, the avian strains of $E$. coli were considered as not causing any important disease in man and animals, so were not of much zoonotic significance. But as APEC share not only identical serotypes but specific virulence factors also with human pathogens, their zoonotic potential is now under consideration. Some authors have reported that $E$. coli from poultry is the food animal source most closely linked to human Extra intestinal $E$. coli (ExPEC) suggested a potential zoonotic risk (MANGES \& JOHNSON, 2012; MELLATA, 2013). A multiplex PCR targeting five genes (hly $\mathrm{F}$, iss, iro $\mathrm{N}$, omp $\mathrm{T}$ and iut $\mathrm{A}$ ) has been identified as being the most significantly associated with highly pathogenic APEC (SYLVESTER \& SING, 2002). These genes were also reported in $E$. coli isolated from urinary tract infection (CYOIA et al., 2015) and they were 


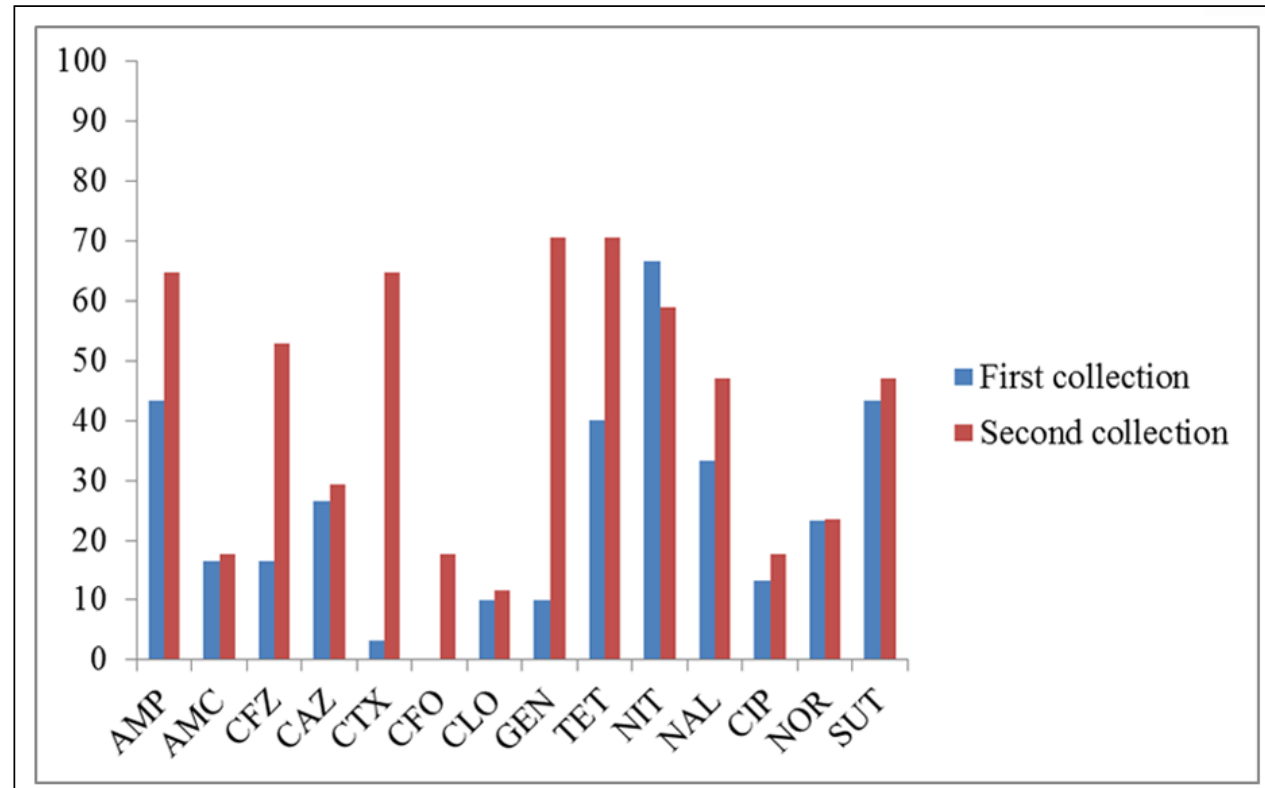

Figure 2 - Frequency of antimicrobial resistance to Escherichia coli strains obtained from first and second collection from poultry litter in Ituverava, SP, Brazil, 2018. *Ampicillin (AMP); AmoxicillinClavulanic Acid (AMC); Cefazolin (CTZ); Ceftazidime (CEF); Cefotaxime (CTX); Cefoxitin (CFO); Chloramphenicol (CLO); Gentamicin (GEN); Tetracycline (TET); Nitrofurantoin (NIT); Nalidixic Acid (NAL); Ciprofloxacin (CIP); Norfloxacin (NOR); Trimethoprim-Sulfamethoxazole(SUT).

also reported in conjugative plasmid in human $E$. coli strains isolated from sepsis in Brazil, indicated a possible zoonotic risk (KOGA et al., 2014).

KOGA et al., (2015) examined E. coli strains isolated from chicken carcasses obtained from conventional and free-range poultry system. Among them the strains from the conventional system showed a lower frequency to four of the five APEC genes examined in the present study $(h l y \mathrm{~F}-47.1 \%$; iutA54.5\%; iss-35.5\%; omp T-52.9\%; iroN-28.9\%), except for iroN gene. Agreeing with KOGA et al., (2015), STELLA et al., (2016) examined 91 E. coli strains isolated from feces of healthy broiler chickens and their results (hly $\mathrm{F}-49.4 \%$; iutA-43.0\%; iss-31.7\%; omp $\mathrm{T}$ $46.0 \%$; iro $\mathrm{N}-22.0 \%$ ) also showed a higher frequency for the $i r o \mathrm{~N}$ gene than the present study.

DE CARLI et at (2015) examined 138 $E$. coli isolates from tissue and organs of chickens suspected to have colibacillosis in poultry flocks in Brazil, they reported high frequencies of APEC pathogenic genes, $h l y \mathrm{~F}-100 \%$; omp $\mathrm{T}-100 \%$; iroN$98.8 \%$; iss- $96.3 \%$ and iutA-81.5\%. These results agree with those reported by JEONG et al., (2012) also from APEC strains from infected chickens iroN-

Table 3 - Prevalence of antimicrobial resistance among Escherichia coli strains isolated from poultry litter in Ituverava, SP, Brazil, 2018.

\begin{tabular}{lcc}
\hline & First positive collection \\
Prevalence of antimicrobial resistance & Number of isolates & Second positive collection \\
& 2 & Number of isolates \\
\hline No resistance detected & 7 & -- \\
\hline Resistance to 1 or 2 antimicrobials & 7 & 3 \\
\hline Resistance to 3 or 4 antimicrobials & 14 & 11 \\
\hline Resistance to 5 or 10 antimicrobials & ---- & 2 \\
\hline Resistance to 11 to 14 antimicrobials & & 1 \\
\hline
\end{tabular}


$100 \%$; omp T-94.1\%; hly $\mathrm{F}-87.1 \% ;$ iss $-78.2 \%$ and iucD-73.3\%. In another way CUNHA et al., (2017) examined E. coli isolates from chickens' cases of colibacillosis and GAZAL et al., (2015) examined E. coli from avian organic fertilizer, in both was found a great number of characteristic ExPEC genes found in human infection among the E.coli isolates from chicken, what reinforce an overlapping of characteristics between APEC and human ExPEC, leading to the hypothesis of a zoonotic potential risk of poultry strains (GAZAL et al., 2015).

The genetic profiles of $E$. coli strains isolated in the present trial showed different profiles distribution; however, more than $50 \%$ of the identified profiles were concentrate in two profiles $h l y \mathrm{~F}+i s s+o m p \mathrm{~T}+i u t \mathrm{~A} \quad(33.3 \%)$ and $h l y \mathrm{~F}+i s s+i u t \mathrm{~A}$ $(20.0 \%)$ what agree with the results reported by STELLA et al., (2016) which indicated the most frequent profile as iro $\mathrm{N}+o m p \mathrm{~T}+i s s+i u t \mathrm{~A}+h l y \mathrm{~F}$ followed by omp $\mathrm{T}+i u t \mathrm{~A}+h l y \mathrm{~F}$ representing $50 \%$ of the genetic profiles recovered from $E$. coli strains isolated from feces of healthy broiler chickens. The virulence genes examined in the present study included those encoding plasmid-associated virulence genes (JOHNSON et al., 2006) associated with APEC strains and human ExPEC strains as well as antibiotic resistance genes often carried on the same genetic elements (SKYBERG et al., 2006). Also, there is a well-documented history of transfer of $E$. coli strains and their plasmids from poultry to humans (VAN DEN BOGAARD et al., 2001).

Antimicrobial resistance in bacteria isolated from food animals is often associated with the use of antibiotics in livestock (MARSHALL \& LEVY 2011; MELLATA, 2013). Even though many antimicrobials such as tetracycline, $\beta$-lactams and quinolones are prohibited as growth promoters in Brazil (BRASIL $2003,2009)$ the frequency of antimicrobial resistance among the $E$. coli strains isolated in the present study was high for all these antimicrobial drugs. According to KOGA et al., (2015) the E. coli strains from conventional poultry system showed a higher frequency of antimicrobial resistance for $\beta$ lactams, chloramphenicol, tetracycline and quinolones drugs than the present study while the cephalosporins, aminoglycosides and nitrofurantoin showed a lower frequency of antimicrobial resistance when compared with the present study. STELLA et al., (2016) reported a frequency of $100 \%$ of resistance to cephalothin, erythromycin, streptomycin, neomycin, ampicillin and amoxicillin. Also, FURTULA et al., (2010) from Canada and ADELOWO et al., (2014) from Nigeria reported a high level of resistance for tetracycline, sulphamethoxazole and aminoglycosides among $E$. coli from poultry showing a great dissemination the antimicrobial resistance in the poultry industry.

Tetracycline was the antimicrobial with the highest frequency of resistance in the second positive collection in the present study. The high frequency of resistance can be explained, in part, because it has a low price and is easily obtained, which leads to an indiscriminate and incorrect uses. According to KHAN et al., (2014) the use of tetracyclines in poultry production is very common, which is generating a significant increase in resistance findings what was also reported by KOGA et al., (2015) in Brazil and similar data were also provided for other countries (FURTULA et al., 2010; ADELOWO et al., 2014).

$\beta$ lactam antimicrobials, especially the third generation cephalosporins are the most common treatment for human infections by Enterobacteriacea. However, many resistant bacteria to these drugs have emerged worldwide (FURTULA et al., 2010; PITOUT, 2012) what agree with the high frequency of antimicrobial resistance to cephalosporins reported among the E. coli isolates in the present study, and in STELLA et al., (2016).

Quinolones are broad-spectrum agents that are often used for enteric infections and human urinary tract therapy (PITOUT, 2012). However, the presence of quinolone-resistant $E$. coli in animals has increased (ADELOWO et al., 2014). Our results indicated a high frequency of resistance to nalidixic acid in strains isolated from poultry litter $(50.0 \%)$. These results agree with KOGA et al., (2015) who reported a high frequency of resistance to nalidixic acid $(70.0 \%)$ in $E$. coli isolates obtained from poultry in conventional system of production (farming system), and also with CARVALHO et al., (2015) who reported a nalidixic acid resistance of $75.0 \%$ from $E$. coli isolates obtained in broiler houses in Rio Grande do Sul, Brazil, showing a necessity of attention to the critical use of antimicrobials used in treatment of human infections.

GAZAL et al., (2015) examined sixty-four E. coli isolates from avian organic fertilizer in Brazil that was a final product of the poultry litter composting process, the windrowing process of a 10 days of a fermentative process. Most isolates were resistant to tetracycline (35.9\%); amoxicillin (20.35); ampicillin (18.7\%); streptomycin (17.1\%) and trimethoprimsulfamethoxazole $(12.5 \%)$. Results of the present study showed a higher level of resistance for these antimicrobial drugs, likely due to the intensity of use of the antimicrobial drugs in the preventive treatment of the different chicken flocks. Most of these antimicrobial resistance genes are associated with 
virulence genes present in the same APEC and ExPEC plasmids (JOHNSON et al., 2006). The great number of $E$. coli isolates showing multidrug resistance to 5 to 10 drugs in the present study reinforced this probably resistance linked to plasmid origin. Therefore, it seems very important to pay more attention to the spread of resistance through such poultry production systems and the necessity of a stricter regulation of antimicrobial usage in the production systems with close interaction between humans and animals.

SONODA et al., (2012) reported that the composting method, piled (windrowing) did not significantly reduced the pathogenic bacterial population present in the litter, it means that the period of 10-12 days of composting seemed not to be sufficient to eliminate the virulence factors and antimicrobial resistance genes linked to plasmids inside the pathogenic bacteria. Results in the present study agreed with those from SONODA et al., (2012), which showed that the sanitary gap period of 10 to 12 days among the flocks grow out used in the poultry house in Brazil is not enough to permit a correct composting process with the destruction of pathogenic E.coli cells. We reported APEC strains with virulence and antimicrobial resistance genes present in litter samples after 15 days of the windrowing process, it means that the process should have a amplified period of composting and when necessary a correction of the $\mathrm{C} / \mathrm{N}$ balance by adding more green mass to the litter to permit a correct composting process.

\section{CONCLUSION}

The strains characterized in this research with a high frequency of antimicrobial resistance, associated with several virulence genes showed that $E$. coli strains may be present in organic fertilizers after fifteen days of the fermentative process usually used by Brazilian farmers what represents a risk for the dissemination of these genes in the environment, to avoid the period of composting of avian organic fertilizer must be amplify.

\section{ACKNOWLEDGEMENTS}

This study was financed by the Coordenação de Aperfeiçoamento de Pessoal de Nível Superior (CAPES), Brasil - Finance code 001."

\section{DECLARATION OF CONFLICT OF INTERESTS}

The authors declare no conflict of interest. The founding sponsors had no role in the design of the study, in the collection, analyses, or interpretation of data; in the writing of the manuscript, and in the decision to publish the results.

\section{AUTHORS' CONTRIBUTIONS}

JMAA,JMM conceived, designed and supervised the experiment. JMAA, MVC, MMB performed the experiments and data collection. JMAA, JMM prepared the draft of the manuscript. All authors critically revised the manuscript and approved the final version.

\section{REFERENCES}

ABPA (Associação Brasileira de Proteina Animal). Relatório Annual, 2018. Available from: <http://abpa-br.com.br/setores/ avicultura/publicacoes/relatorios-anuais>. Accessed: Jul. 15, 2018.

ADELOWO, O. O., et al. Antibiotic resistance and resistance genes in Escherichia coli from poultry farms, southwest Nigeria. Journal of Infections in Developing Countries, v.8, p.11031112, 2014. Available from <https://orbit.dtu.dk/en/publications/ antibiotic-resistance-and-resistance-genes-in-escherichia-coli-fr $>$. Accessed: Jul. 15, 2018. doi: 10.3855/jidc.4222.

ASAI, T., et al. Control of the development and prevalence of antimicrobial resistance in bacteria of food animal origin in Japan: a new approach for risk management of antimicrobial veterinary medicinal products in Japan. Foodborne Pathogens and Disease, v.11, p.171-176, 2014. Available from: <https://www.ncbi.nlm. nih.gov/pubmed/24387636>. Accessed: Oct. 30, 2018. doi: 10.1089/fpd.2013.1649.

BRASIL. Ministério da Agricultura, Pecuária e Abastecimento. Instrução Normativa n. 007 de 17 de maio de 1999. Normas disciplinadoras para a produção, tipificação, processamento, envase, distribuição, identificação e certificação da qualidade de produtos orgânicos, sejam de origem animal ou vegetal. Acesso em 20 de janeiro de 2019. Available from: $<\mathrm{http} / / / \mathrm{www}$.agricultura. gov.br>. Accessed: Jan. 20, 2019.

BRASIL. Ministério da Agricultura, Pecuária e Abastecimento. Instrução Normativa, n. 9 de 27 de junho de 2003. Pró́be a fabricação, a manipulação, o fracionamento, a comercialização, a importação e o uso dos princípios ativos cloranfenicol e nitrofuranos e os produtos que contenham estes princípios ativos, para uso veterinário e susceptível de emprego na alimentação de todos os animais e insetos", Instrução Normativa, no. 9. 2003. Available from: $<$ https://www.diariodasleis.com.br/legislacao/federal/25330-proibea-fabricacao-a-manipulacao-o-fracionamento-a-comercializacaoa-importacao-e-o-uso-dos-principios-ativos-cloranfenicol-e-nitrofuranos-e-os-produtos-que-contenham-estes-principios-ativos-pa. html>. Accessed: Jul. 20, 2018.

BRASIL. Ministério da Agricultura, Pecuária e Abastecimento. Instrução Normativa, n. 26 de 09 de julho de 2009. "Regulamento técnico para a fabricação, o controle de qualidade, a comercialização e o emprego de produtos antimicrobianos de uso veterinário," Instrução Normativa 26. 2009. [Online]. Available from: <http://sistemasweb. agricultura. gov.br/sislegis/action/detalhaAto.do?method=visualizarAt oPortalMapa\&chave=1984822284>. Accessed: Jul. 20, 2018.

BROOKS, J.P., et al. Pathogen re-colonization of in-house composted and noncomposted broiler litter. Journal of Applied Poultry Research, v.24, p.157-167, 2015. Available from: $<$ https:// academic.oup.com/japr/article/24/2/157/775697>. Accessed: Oct. 15, 2019. doi: $10.3382 / \mathrm{japr} / \mathrm{pfv} 013$. 
BUSTAMANTE, M. A., et al. Co-composting of distillery wastes with animal manures: carbon and nitrogen transformations in the evaluation of compost stability. Chemosphere, v.72, p.551-557, 2008. Available from: $<$ https://www.ncbi.nlm.nih.gov/pubmed/18466954>. Accessed: Oct. 20, 2018. doi: 10.1016/j.chemosphere.2008.03.030.

CARVALHO, D., et al. Antimicrobial susceptibility and pathogenicity of Escherichia coli strains of environmental origin. Ciência Rural, v.45, p.1249-1255, 2015. Available from: <https:// www.redalyc.org/pdf/331/33139460016.pdf>. Accessed: Oct. 07, 2018. doi: $10.1590 / 0103-8478$ cr20141020.

CLSI - CLINICAL AND LABORATORY STANDARDS INSTITUTE. Performance Standards for Antimicrobial Disk and Dilution Susceptibility Tests for Bacteria Isolated from Animals. Approved Standard, CLSI Document M31-A3, Clinical and Laboratory Standards Institute (CLSI), Wayne, Pa, USA, 3rd edition, 2008. Available from: <http://www.dbt.univr.it/documenti/ OccorrenzaIns/matdid/matdid485539.pdf $>$. Accessed: Jul. 20, 2018.

CLSI-CLINICALANDLABORATORY STANDARDS INSTITUTE. Performance standards for antimicrobial susceptibility testing; 23rd informational supplement. CLSI Document M100-S23, CLSI, Wayne, Pa, USA, 2013. Available from: <https://www.facm.ucl.ac.be/intranet/ CLSI/CLSI-M100S23-susceptibility-testing-2013-no-protection.pdf > Accessed: Jul. 20, 2018.

CUNHA, M. P. V., et al. Pandemic extra-intestinal pathogenic Escherichia coli (ExPEC) clonal group O6-B2-ST73 as a cause of avian colibacillosis in Brazil. PLOS ONE, v.12, n.6: e0178970, 2017. Available from: <https://www.ncbi.nlm.nih.gov/pmc/ articles/PMC5464619/>. Accessed: Jul. 04, 2018. doi: 10.1371/ journal.pone.0178970.

CYOIA, P. S., et al. Presence of virulence genes and pathogenicity islands in Extraintestinal pathogenic Escherichia coli isolated in Brazil. The Journal of Infection in Developing Countries, v.9, p.1068-1075, 2015. Available from: <https://hal-riip.archivesouvertes.fr/pasteur-01351916/document $>$. Accessed: Sep. 20, 2018. doi: $10.3855 /$ jidc. 6683 .

DE CARLI, S., et al. Virulence gene content in Escherichia coli isolates from poultry flocs with clinical signs of colibacillosis in Brazil. Poultry Science, v.94, p.2635-2640, 2015. Available from: $<$ https://www.ncbi.nlm.nih.gov/pubmed/26371329>. Accessed: Oct. 10, 2018. doi: 10.3382/ps/pev256.

EWERS, C., et al. Intestine and environment of the chicken as reservoirs for extra-intestinal pathogenic Escherichia coli strains with zoonotic potencial. Appl. Environ. Microbiol, v.75, p.184-192, 2009. Available from: <https://www.ncbi.nlm.nih.gov/pmc/articles/PMC2612213/>. Accessed: Oct. 10, 2018. doi: 10.1128/AEM.01324-08.

FURTULA, V., et al. Veterinary pharmaceuticals and antibiotic resistance of Escherichia coli isolates in poultry litter from commercial farms and controlled feeding trials. Poultry Science, v.89, p.180-188. 2010. Available from: <https://www.ncbi.nlm.nih. gov/pubmed/20008817>. Accessed: Jun. 19, 2018. doi: 10.3382/ ps.2009-00198.

GAZAL, L.E.S., et al. Presence of pathogenicity islands and virulence genes of extraintestinal pathogenic Escherichia coli (ExPEC) in isolates from avian organic fertilizer. Poultry Science, v.94, p.3025-3033, 2015. Available from: <https://academic.oup. com/ps/article/94/12/3025/2461216>. Accessed: Jul. 20, 2018. doi: $10.3382 / \mathrm{ps} / \mathrm{pev} 278$.
ISHII, S. T., et al. Factors controlling long-term survival and growth of naturalized Escherichia coli populations in temperate field soils. Microbes Environment, v.25, p.8-14, 2010. doi:10.1264/jsme2.ME09172. Available from: <https://www. researchgate.net/publication/51131167_Factors_Controlling Long-Term_Survival_and_Growth_of_Naturalized_Escherichia coli_Populations_in_Temperate_Field_Soils $>$. Accessed: Oct. 20, 2018. doi: $10.12 \overline{6} 4 / \overline{\text { jsme2.ME09172. }}$

JEONG, Y. W., et al. Pathotyping avian pathogenic Escherichia coli strains in Korea. Journal of Veterinary Science, v.13, p. 145-152, 2012. Available from: <https://www.ncbi.nlm.nih.gov/pubmed/22705736. Accessed: Jul. 08, 2018. doi: 10.4142/jvs.2012.13.2.145

JOHNSON, T. J., et al. DNA sequence of a ColV plasmid and prevalence of selected-encoded virulence genes among avian Escherichia coli strains. Journal of Bacteriology, v.188, p.745758, 2006. Available from: $<$ https://jb.asm.org/content/188/2/745>. Accessed: Jun. 30, 2018. doi: 10.1128/JB.188.2.745-758.2006

JOHNSON, T. J., et al. Identification of minimal predictors of avian pathogenic Escherichia coli virulence for use as a rapid diagnostic tool. Journal of Clinical Microbiology, v.46, p.3987-3996, 2008. Available from: $\quad<$ https://www.ncbi.nlm.nih.gov/pmc/articles/PMC2593276/>. Accessed: Jul. 25, 2018. doi: 10.1128/JCM.00816-08

JOHNSON, T. J., et al. Associations between multidrug resistance, plasmid content, and virulence potential among extraintestinal pathogenic and commensal Escherichia coli from humans and poultry. Foodborne Pathogens and Disease, vol.9, p.37-46, 2012. $<$ https://www.ncbi.nlm.nih.gov/pubmed/21988401>. Accessed: Oct. 24, 2018. doi: 10.1089/fpd.2011.0961.

KHAN, M.S., et al. Isolation of non-plasmid Multidrug resistant Escherichia coli from poultry wastes in Chittagong Region, Blangladesh. Journal Bacteriology \& Parasitology, v.5, p.1-7, 2014. Available from: $<$ https://www.longdom.org/open-access/isolationand-identification-of-nonplasmid-multidrug-resistant-ecoli-frompoultry-wastes-in-chittagong-region-2155-9597.1000182.pdf $>$. Accessed: Oct. 10, 2018. doi: 10.4172/2155-9597.1000182

KESKIMAKI, M., et al. EPEC, EAEC and STEC in stool specimens: Prevalence and molecular epidemiology of isolates. Diagnostic Microbiology and Infectious Disease, v.40, p.151 -156 , 2001. Available from: <https://www.sciencedirect.com/ science/article/abs/pii/S0732889301002656?via\%3Dihub $>$. Accessed: Sep. 12, 2017. doi: 10.1016/s0732-8893(01)00265-6

KOGA, V. L. et al. Molecular screening of virulence genes in extraintestinal pathogenic Escherichia coli isolated from human blood culture in Brazil. BioMed Research International, vol. 2014, Article ID 465054, 9 pages, 2014. Available from: <https:// www.hindawi.com/journals/bmri/2014/465054/>. Accessed: Oct. 14, 2018. doi: 10.1155/2014/465054.

KOGA, V.L., et al. Comparison of Antibiotic Resistance and Virulence Factors among Escherichia coli Isolated from Conventional and FreeRange Poultry. Biomed Research International, 8p., 2015. Available from: $\quad<$ https://www.hindawi.com/journals/bmri/2015/618752/>. Accessed: Oct. 14, 2018. doi: 10.1155/2015/618752.

KONEMAN, E. W., et al. Color atlas and textbook of diagnostic microbiology, 5th Ed. Lippincott, 1395p., 1997.

MAGIORAKOS, A. P., et al. Multidrug-resistant, extensively drugresistant and pandrug-resistant bacteria: an international expert 
proposal for interim standard definitions for acquired resistance. Clinical Microbiology Infection, v.18, p.268-281, 2012. Available from: $<$ https://www.clinicalmicrobiologyandinfection.com/article/ S1198-743X(14)61632-3/fulltext>. Accessed: Oct. 14, 2018. doi: 10.1111/j.1469-0691.2011.03570.x.

MANGES, A. R.; JOHNSON, J. R. Food-borne origins of Escherichia coli causing extraintestinal infections. Clinical Infectious Diseases, vol.55, p.712-719, 2012. Available from: $<$ https://academic.oup.com/cid/article/55/5/712/351325>. Accessed: Oct. 14, 2018. doi: 10.1093/cid/cis502.

MARTIN, S. A. et al. Microbiological survey of Georgia poultry litter: Journal of Applied Poultry Research, v.7, p.90-98. 1998. Available from: <https://academic.oup.com/japr/article/7/1/90/729969>. Accessed: Oct. 14, 2018. doi: 10.1093/japr/7.1.90.

MARSHALL, B. M.; LEVY, S. B. Food animals and antimicrobials: impacts on human health. Clinical Microbiology Reviews, vol.24, p.718-733, 2011. Available from: $<\mathrm{https} / / \mathrm{cmr}$. asm.org/content/24/4/718>. Accessed: Oct. 30, 2018. doi: 10.1128/ CMR.00002-11.

MELLATA, M. Human and avian extraintestinal pathogenic Escherichia coli: infections, zoonotic risks, and antibiotic resistance trends. Foodborne Pathogens and Disease, v.10, p.916-932, 2013. Available from: <https://www.liebertpub.com/ doi/10.1089/fpd.2013.1533>. Accessed: Oct. 30, 2018. doi: 10.1089/fpd.2013.1533.

OLAIMAT, A. N.; HOLLEY, R. A. Factors influencing the microbial safety of fresh produce: A review. Food Microbiology, v.32, p.1-19, 2012. Available from: <https://www.sciencedirect. com/science/article/pii/S0740002012000986?via\%3Dihub>. Accessed: Oct. 30, 2018. doi: 10.1016/j.fm.2012.04.016.

PITOUT, J. D. D. Extraintestinal pathogenic Escherichia coli: a combination of virulence with antibiotic resistance. Frontiers in Microbiology, v.3, p.1-7, 2012. Available from: <https://www. ncbi.nlm.nih.gov/pmc/articles/PMC3261549/>. Accessed: Nov. 28, 2018. doi: 10.3389/fmicb.2012.00009.

SILVA, N., et al. Efeitos de tratamento sobre a carga bacteriana de cama de aviário reutilizada em frango de corte. Comunicado Técnico 467, EMBRAPA, Concordia, SC, 2007. Available from: $<$ https://ainfo.cnptia.embrapa.br/digital/bitstream/item/58058/1/ CUsersPiazzonDocuments467.pdf $>$. Accessed: Nov. 28, 2018.

SKYBERG, J. A., et al. Acquisition of avian pathogenes Escherichia coli plasmids by a commensal $E$. coli isolate enhances its abilities to kill chicken embryos, grow in human urine and colonize the murine kidney. Infection and Immunity, v.74, p.6287-6292, 2006. Available from: <https://iai.asm.org/content/74/11/6287>. Accessed: Nov. 28, 2018. doi: 10.1128/IAI.00363-06.
SONG, C., et al. Comparison of bacterial community structure and dynamics during the thermophilic composting of diferente types of solid wastes: anaerobic digestion residue, pig manure and chicken manure. Microbial Biotechnology, v.7, p.424-433, 2014. Available from: <https://www.semanticscholar.org/paper/ Comparison-of-bacterial-community-structure-and-the-Song-Li/2 dd2043e0506b520dcdbf66a1c9c1270ae64aafd $>$. Accessed: Nov. 28, 2018. doi: 10.1111/1751-7915.12131.

SONODA, L. T., et al. Broiler litter reutilization applying diferente composting concepts. Brazilian Journal of Poultry Science, v.14, p.159-164, 2012. Available from: <http:// www.scielo.br/scielo.php?script $=$ sci arttext\&pid $=\mathrm{S} 1516$ 635X2012000300011>. Accessed: Sep. 24, 2018. doi: 10.1590/ S1516-635X2012000300011.

STELLA, A. E., et al. Characterization and antimicrobial resistance patterns of Escherichia coli isolated from feces of healthy broiler chickens. Arquivos do Instituto Biológico, v.83, p.1-5, 2016. Available from: $<$ http://www.scielo.br/scielo.php?script=sci artte xt\&pid=S1808-16572016000100217>. Accessed: Sep. 24, 2018. doi: $10.1590 / 1808-1657000392014$

SYLVESTER, S. A.; SINGH, S. D. Characterization and immunizing properties of outer membrane proteins (OMPs) of avian E. coli. Indian Journal of Veterinary Pathology, v.26, p.109. 2002. Available from: <https://www.sciencedirect.com/ science/article/abs/pii/S0378111915012202?via\%3Dihub>. Accessed: Sep. 24, 2018. doi: 10.1016/j.gene.2015.10.012.

VAN DEN BOGAARD, A. F., et al. Antibiotc resistance of faecal Escherichia coli in poultry, poultry farms and poultry slaughterers. Antimicrobial Chemotherapy, v.47, p.763-771, 2001. Available from: <https://academic.oup.com/jac/article/47/6/763/756186>. Accessed: Oct. 30, 2018. doi: 10.1093/jac/47.6.763.

VAZ, C. S. L, et al. Interventions to reduce the bacterial load in recycled broiler litter. Poultry Science, v.96, p.25872594, 2017. Available from: <https://academic.oup.com/ps/ article/96/8/2587/3078939>. Accessed: Oct. 30, 2018. doi: $10.3382 / \mathrm{ps} / \mathrm{pex} 063$.

WILKINSON, K. G., et al. Effect of heating and aging of poultry litter on the persistence of enteric bactéria. Poultry Science, v.90, p.10-18, 2011. Available from: <https://academic.oup.com/ps/ article/90/1/10/1511471>. Accessed: Sep. 24, 2018. doi: 10.3382/ ps.2010-01023.

WINKLER, S., et al. Within-house spatial distribution of fecal indicator bacteria in poultry litter. Journal of Environmental Quality Abstract - Environmental Microbiology, 2017. Available from: <https://dl.sciencesocieties.org/publications/jeq/ abstracts/46/5/1003>. Accessed: Nov. 28, 2018. doi: 10.2134/ jeq2017.05.0188 